\title{
Terrestrial isopods (Crustacea: Isopoda: Oniscidea) in termite nests (Blattodea: Termitidae) in a cocoa plantation in Brazil
}

\author{
Jonathas Teixeira Lisboa ${ }^{1,7}$, Erminda da Conceição Guerreiro Couto ${ }^{2}$, \\ Pollyanna Pereira Santos $^{3}$, Jacques Hubert Charles Delabie ${ }^{4,5}$ \& Paula Beatriz Araujo ${ }^{6}$ \\ ${ }^{1}$ Universidade Estadual de Santa Cruz - UESC, Campus Soane Nazaré de Andrade, \\ Rod. Ilhéus-Itabuna, km 16, CEP 45662-900, Ilhéus, BA, Brasil. www.uesc.br/zoologia \\ ${ }^{2}$ Universidade Estadual de Santa Cruz - UESC, Campus Soane Nazaré de Andrade, Rod. Ilhéus-Itabuna, \\ km 16, CEP 45662-900, Ilhéus, BA, Brasil.www.uesc.br/cursos/pos_graduacao/mestrado/ppsat \\ ${ }^{3}$ Universidade Federal de Viçosa - UFV, CEP 36570-000 Viçosa, MG, Brasil. www.pos.entomologia.ufv.br \\ ${ }^{4}$ Departamento de Ciências Agrárias e Ambientais, Universidade Estadual de Santa Cruz - UESC, \\ Campus Soane Nazaré de Andrade, Rod. Ilhéus-Itabuna, km 16, CEP 45662-900, Ilhéus, BA, Brasil. \\ www.uesc.br/dcaa/index.php \\ ${ }^{5}$ Laboratório de Mirmecologia, Convênio UESC/CEPLAC, Centro de Pesquisa do Cacau, \\ CP 7, CEP 45600-000 Itabuna, BA, Brasil. \\ http://www.ceplac.gov.br/Laboratorios/mirmecologia/index.html \\ ${ }^{6}$ Departamento de Zoologia, Instituto de Biociências, \\ Universidade Federal do Rio Grande do Sul-UFRGS, Av. Bento Gonçalves, 9500, prédio 43435, \\ Agronomia, CEP 91501-970, Porto Alegre, RS, Brasil. http://www.ufrgs.br/Carcinologia \\ ${ }^{7}$ Corresponding author: Jonathas Teixeira Lisboa, e-mail: onelisboa@gmail.com
}

LISBOA, J.T., COUTO, E.C.G., SANTOS, P.P., DELABIE, J.H.C. \& ARAUJO, P.B. Terrestrial isopods (Crustacea: Isopoda: Oniscidea) in termite nests (Blattodea: Termitidae) in a cocoa plantation in Brazil. Biota Neotrop. 13(3): http://www.biotaneotropica.org.br/v13n3/en/abstract?short-communication+bn03713032013

\begin{abstract}
Various animals live in termite nests as secondary occupants. Among them are terrestrial isopods. We found five species of terrestrial isopods (Oniscidea) in 17 of 34 termite nests of Nasutitermes in a cocoa plantation near Ilhéus, Bahia, Brazil (in 2 aging and 15 abandoned nests). The 14 active, 1 aging and 2 abandoned nests bore no isopods. The oniscideans were Atlantoscia rubromarginata, an undescribed species of Atlantoscia (Philosciidae), Pudeoniscus birabeni, P. obscurus (Pudeoniscidae) and Neotroponiscus carolii (Bathytropidae). Of the 146 individuals collected, 122 were A. rubromarginata. Due to the absence of isopods in active nests, these terrestrial isopods are considered termitariophilous.
\end{abstract}

Keywords: Termitariophilous, Nasutitermes, Atlantoscia.

LISBOA, J.T., COUTO, E.C.G., SANTOS, P.P., DELABIE, J.H.C. \& ARAUJO, P.B. Isópodos terrestres (Crustacea: Isopoda: Oniscidea) em ninhos de térmitas (Blattodea: Termitidae) em uma plantação de cacau no Brasil. Biota Neotrop. 13(3): http://www.biotaneotropica.org.br/v13n3/pt/abstract?shortcommunication+bn03713032013

Resumo: Diversos animais, incluindo isópodos terrestres, vivem em ninhos de térmites como ocupantes secundários. Neste trabalho, foram registradas cinco espécies de isópodos terrestres (Oniscidea) em 17 de 34 ninhos de Nasutitermes estudados em uma plantação de cacau situada próxima a Ilhéus, Bahia, Brasil. Destes ninhos, dois eram decadentes e 15 abandonados. Catorze ninhos ativos, um decadente e dois abandonados não apresentaram isópodos. Foram registrados os oniscídeos Atlantoscia rubromarginata, uma espécie não identificada de Atlantoscia (Philosciidae), Pudeoniscus birabeni, P. obscurus (Pudeoniscidae) e Neotroponiscus carolii (Bathytropidae). Foram coletados 146 indivíduos, dos quais 122 pertenciam à espécie $A$. rubromarginata . Devido à ausência de isópodos em ninhos ativos, estes foram considerados termitariófilos.

Palavras-chave: Termitariófilo, Nasutitermes, Atlantoscia. 


\section{Introduction}

Termites (Blattodea: Termitoidea) are social insects that build mounds, permanent structures, that can be external, within the wood or underground (Xiao et al. 2012). They are considered active diggers exerting great influence on the physical and chemical characteristics of soils by providing an increase in porosity, allowing water retention and air circulation in different soil strata, facilitating the entry of oxygen to other soil organisms in subterraneous nests (Grassé 1986, Lavelle et al. 1997). In addition to these activities, they provide a greater penetration and proliferation of plant roots and also serve as food for a wide variety of predators (Holt \& Lapage 2000). The secondary occupants of termite nests are ants, beetles, spiders, roaches, lizards, species of termites different from those that have built the structure and even parrots, parakeets and the campos flicker (Davis 1942, Camargo 1970, Grassé 1986, Miura \& Matsumoto 1997, Brightsmith 2005, Sanchez-Martinez \& Renton 2009). Termitophilous animals are those that have a necessary relationship with the society of termites (Domingos 1983), spending part or all life in the nest (Cunha $\&$ Brandão 2000). The termitariophilous animals are those that form a voluntary association with termite mounds in search of housing, shelter, food or nesting site (Cunha \& Brandão 2000).

Terrestrial isopods are the Crustacea best adapted to terrestrial life. They are found in forests, fields, deserts and caves, and occupy a wide variety of microhabitats, including the interiors of ant and termite nests (Araujo \& Taiti 2007). There are few studies about the relationship between social insects and terrestrial isopods (Tartally et al. 2004), but some species are known of being closely associated with social insects. In Europe, the myrmecophilous isopod Plathyarthrus schoblii Budde-Lund, 1879 is found in the nests of ants of various genera (Hornung et al. 2005), while the cosmopolitan P. hoffmannseggii Brandt, 1833 inhabits nests of 24 different species of ants (Tartally et al. 2004). In sub-Saharan Africa some species of isopods of the families Platyarthridae, Trichoniscidae, Titaniidae and Schoebliidae are found in the active nests of several genera of termites (Barnard 1932, Paulian de Felice 1950, Kensley 1971, Ferrara \& Taiti 1979). In Mozambique, the termitophilous isopods Schoeblia fulleri (Silvestri, 1917) and S. circularis Budde-Lund, 1909 occupies the nests of termites of the genus Termes Linnaeus, 1758 (Silvestri 1917, Schmidt \& Leistikow 2004). The genus Exalloniscus Stebbing, 1911 is associated with nests of ants and termites in Sumatra and Borneo and elsewhere in Southeast Asia (Schmalfuss 2003, Ferrara et al. 1987). In Asia, the isopod Turanoniscus anacanthotermitis Borutzkii, 1969 was found in nests of the termite Anacanthotermes ahngherianus Jacobson, 1904 (Borutzkii 1969). The members of this genus have flattened depigmented bodies and a reduced number of embryos, and lack ocular apparatus, all of which suggest that the animals have a close association of with ants and termites (Taiti \& Ferrara 1988). Some oniscideans, like the members of the family Titaniidae, are tolerated by the host termites or protected against attacks by their flattened limuloid body shape and by evasive movements (Kensley 1971). To date there is no record of terrestrial isopods in termite mounds in Brazil. This study aims at surveying the species of oniscideans in termite nests collected in a cocoa plantation near Ilhéus, Bahia State, Brazil.

\section{Material and Methods}

The study was conducted in Block I of the experimental areas of the Centro de Pesquisas do Cacau (CEPEC/CEPLAC) (14 45' $16^{\prime \prime} \mathrm{S}$, $39^{\circ} 13$ ' $50^{\prime}$ ' W), 40 ha, in a system where the cocoa trees are shaded by exotic trees, receive no fertilization or insecticides or fungicidal spraying. Almost all of the experimental area is surrounded by lands with the same system of husbandry. The study site is the Brazilian
Atlantic Forest and some forest remnants are near the experimental area.

The termite nests examined in this study are those investigated by Santos (2008) and Santos et al. (2010) in a study of ants associated with termites. In that study between May 2006 and September 2007 the termites were removed from the substrate and placed in plastic bags, labelled and taken to the Centro de Pesquisas do Cacau (CEPEC) at Ilhéus. In the laboratory, the nests were cut into portions five inches thick for easy removal of the present fauna, which was extracted with the aid of forceps and fixed in $80 \%$ alcohol (Santos 2008). We followed the classification of Santos (2008) regarding the degree of activity in the nest: Active colonies (AT) - the queen, eggs, juveniles, soldiers and workers are present; Aging colonies (AG) - members of the royal caste and juveniles missing and workers in lower proportion than the soldiers; Abandoned nests (AB) - absence of any termites.

\section{Results}

A total of 34 nests constructed by Nasutitermes spp. were sampled. They were built from ground level to height of $4.5 \mathrm{~m}$ in trees. Their degrees of activity were 14 active, 3 aging and 17 abandoned nests. Oniscidea were not found in the 14 active nests. They were present in a total of 17 nests: 2 aging and 15 abandoned, from ground level to $3.7 \mathrm{~m}$ high (Table 1). One aging and two abandoned bore no Oniscidea.

From the 146 specimens collected (Figure 1), most were Atlantoscia rubromarginata Araujo \& Leistikow, 1999 (84\%) (Table 1). This species was found in abandoned and aging nests from the ground up to $3.7 \mathrm{~m}$ high. The second most common species was Pudeoniscus birabeni Vandel, 1963 (6\%). The other three species were Pudeoniscus obscurus Lemos de Castro, 1973, Neotroponiscus carolii Arcangeli, 1936 and Atlantoscia sp.. They comprised only five individuals each.

They had different distributions. The specimens of Neotroponiscus carolii found in this study were in abandoned nests more than two meters high.

\section{Discussion}

The present study is the first report of the occurrence of terrestrial isopods in termite nests in Brazil. Atlantoscia rubromarginata was the most abundant species of Oniscidea we encountered. It was found in all but the two highest of the aging and abandoned termitaria; that is from ground level up to $3.7 \mathrm{~m}$ high.

The genus Atlantoscia presently comprises five described species - A. floridana Van Name, 1940, A. rubromarginata Araujo \& Leistikow, 1999, A. petronioi Campos-Filho, Contreira and LopesLeitzke, 2012, A. ituberasensis Campos-Filho, Lisboa and Araujo 2013 and A. sulcata Campos-Filho, Lisboa and Araujo 2013 (CamposFilho et al 2013). Atlantoscia. floridana occurs in coastal areas from Florida to Uruguay (Leistikow 2001) in nests of the ants Camponotus rufipes Fabricius, 1775 and Odontomachus affinis Guerin-Meneville, 1844 (Lemos de Castro 1985). It is the most frequent and abundant in diversity studies of Oniscidea conducted in southern Brazil (Araujo \& Bond-Buckup 2005, Lopes et al. 2005, Almerão et al. 2006, Quadros \& Araujo 2008) and can reach population densities of up to 1,040 individuals per $\mathrm{m}^{2}$.

We collected a limited number of individuals of another undescribed species of Atlantoscia. Males are always selected for the holotypes of Atlantoscia and only one male of this species was collected, together with four females. The species will be described when additional material becomes available. Here we cite it as Atlantoscia $\mathrm{sp}$. This species was present only in two nests, one abandoned and at ground level, and an aging one $3.5 \mathrm{~m}$ high (Table 1). 
(A)
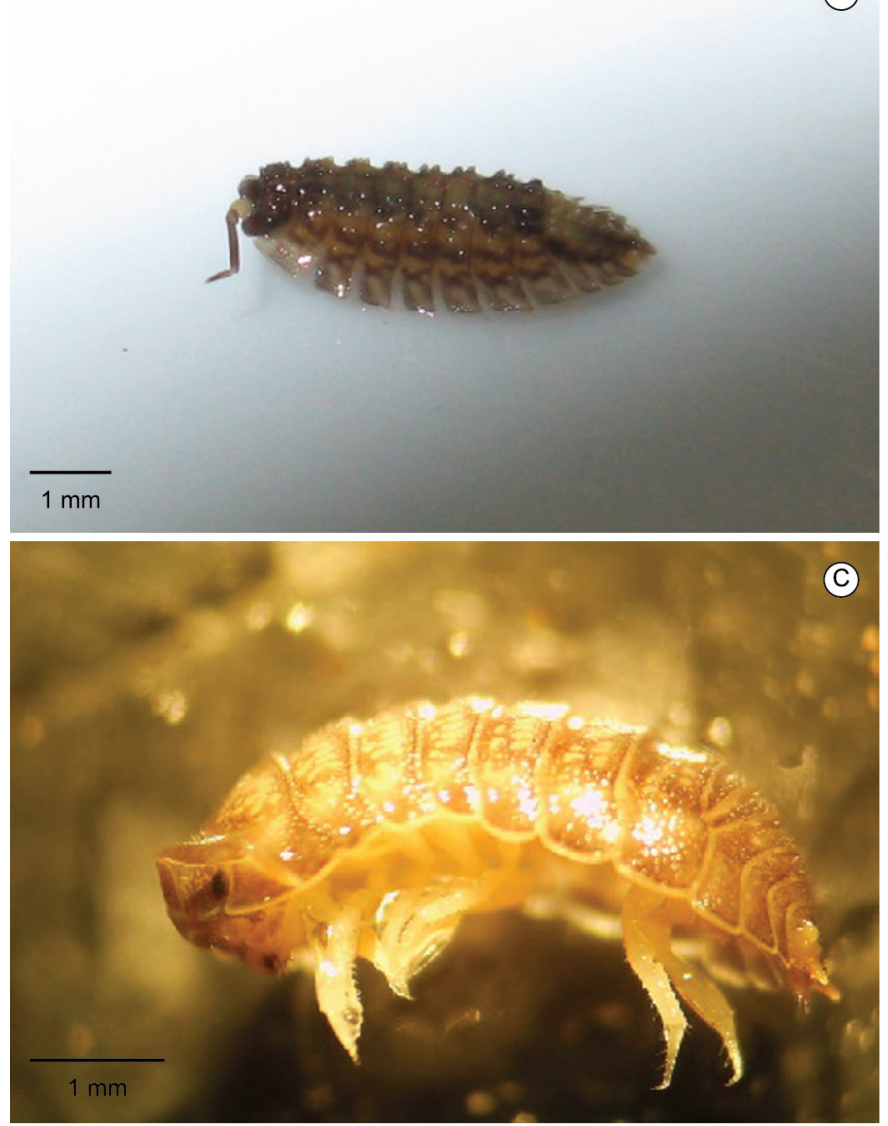

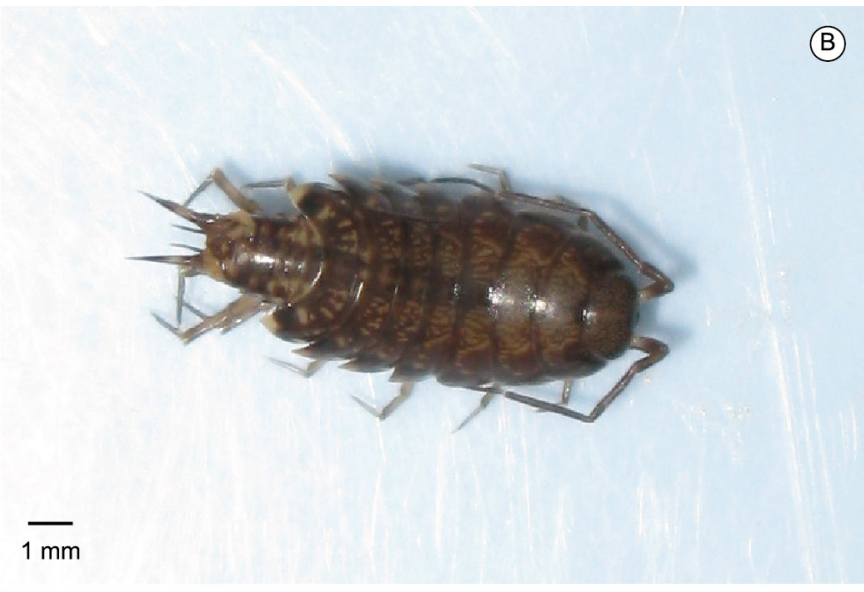

(D)

Figure 1. Isopods collected in the nests of Nasutitermes spp. in cacao plantations in Ilhéus, Bahia, Brazil: (A) Neotroponiscus carolii; (B) Atlantoscia rubromarginata; (C) Pudeoniscus birabeni and (D) Pudeoniscus obscurus.

Table 1. Numbers of individuals of five species of terrestrial isopods in 17 Nasutitermes nests. Nests were classified by activity level and height. AB $=$ abandoned, $\mathrm{AG}=$ aging.

\begin{tabular}{cccccccc}
\hline Nest & $\begin{array}{c}\text { Height above } \\
\text { ground (m) }\end{array}$ & $\begin{array}{c}\text { Neotroponiscus } \\
\text { carolii }\end{array}$ & $\begin{array}{c}\text { Atlantoscia } \\
\text { rubromarginata }\end{array}$ & $\begin{array}{c}\text { Atlantoscia } \\
\text { sp. 2 }\end{array}$ & $\begin{array}{c}\text { Pudeoniscus } \\
\text { birabeni }\end{array}$ & $\begin{array}{c}\text { Pudeoniscus } \\
\text { obscurus }\end{array}$ & Total \\
\hline AB & - & - & 8 & - & - & - & 8 \\
$\mathrm{AB}$ & - & - & 13 & - & - & - & 13 \\
$\mathrm{AB}$ & - & - & 1 & - & 2 & - & 3 \\
$\mathrm{AB}$ & - & - & 19 & - & 4 & 1 & 24 \\
$\mathrm{AB}$ & - & - & 12 & - & 2 & 4 & 18 \\
$\mathrm{AB}$ & - & - & 22 & - & - & - & 22 \\
$\mathrm{AB}$ & - & - & - & 2 & 1 & - & 3 \\
$\mathrm{AB}$ & 0.8 & - & 1 & - & - & - & 1 \\
$\mathrm{AB}$ & 1.6 & - & 5 & - & - & - & 5 \\
$\mathrm{AB}$ & 2 & - & 14 & - & - & - & 14 \\
$\mathrm{AB}$ & 2.1 & - & 18 & - & - & - & 18 \\
$\mathrm{AB}$ & 2.1 & 3 & 1 & - & - & - & 4 \\
$\mathrm{AB}$ & 2.4 & 1 & - & - & - & - & 1 \\
$\mathrm{AB}$ & 3.2 & 1 & 1 & - & - & - & 2 \\
$\mathrm{AB}$ & 3.5 & - & 5 & - & - & - & 5 \\
$\mathrm{AG}$ & 3.5 & - & 1 & 3 & - & - & 4 \\
$\mathrm{AG}$ & 3.7 & - & 1 & - & - & - & 1 \\
$\mathrm{Total}$ & & 5 & 122 & 5 & 9 & 5 & 146 \\
\hline
\end{tabular}


The genus Neotroponiscus is endemic to forests of the Atlantic coast of South America. It comprises eight species ranging from Pernambuco in northeastern Brazil to Argentina (Souza-Kury 1998). Neotroponiscus carolii has been recorded in the states of Sergipe, Bahia and Espirito Santo (Souza-Kury 1998). It is found on fallen logs and litter, and has been cited as myrmecophilous, being associated with Camponotus rufipes (Lemos de Castro 1970).

The family Pudeoniscidae is endemic to Brazil. It comprises only four species; two in Pudeoniscus and two in Brasiloniscus Lemos de Castro, 1973 (Schmidt \& Leistikow 2004). Pudeoniscus is endemic to the Atlantic Forest. Previously P. birabeni (Schmalfuss 2003) had been recorded only from the states of Rio de Janeiro and São Paulo (Souza-Kury 1998), and P. obscurus only from the state of São Paulo (Lemos de Castro 1973, Magrini et al. 2010). We report for the first time, the two species occurring in Bahia State, about 1,000 kilometres further north. Pudeoniscus birabeni is the smallest member of the genus, never exceeding $5 \mathrm{~mm}$ in length (Lemos de Castro 1973). The specimens examined in this study were all in abandoned nests on the ground. Both species of Pudeoniscus have the ability to roll up into a ball (Lemos de Castro 1973). This ability is said to reduce water loss and also serves as protection against predators (Schmalfuss 1984).

Terrestrial isopods are important elements of the soil fauna. In a study carried out by Podgaiski et al. (2007) on the use of natural and artificial microhabitats by invertebrates in the Atlantic Forest of Rio Grande do Sul, isopods represented $17 \%$ of the total fauna under tiles and $23 \%$ of that in the litter. In the particular environment of termite nests, terrestrial isopods represented approximately $7 \%$ of all arthropods collected (Santos 2008). In our study, it was found, however, that the terrestrial isopods use aging and abandoned nests, but not those with active termite colonies. The animals are, therefore, classified as termitariophilous. These are animals that use termite mounds for shelter and as feeing and nesting sites (Cunha \& Brandão 2000). In contrast, termitophilous animals are those that have an obligatory relationship with the termite colony (Domingos 1983) spending part or all life in the nest (Cunha \& Brandão 2000).

Most Oniscidea feed on decaying matter, both vegetable and animal. Abandoned termite nests are rich in organic material accumulated by its builders and by other animals that utilise these microhabitats (Santos 2008), which could be used as a food source for terrestrial isopods. Another factor that may lead them to operate or inhabit such nests is the structure itself. Isopods require a moist environment and seek dark, humid places. The nests of termites are constructed to maintain moisture and ventilation in their galleries (Agarwal 1979) which provides a favorable environment for the colonization of terrestrial organisms such as crustaceans. The galleries and cavities vary in size, offering different options to the adequacy of this habitat to the isopods. On the other hand, we must consider that the specimens were found colonizing nests abandoned by their builders, where the occupants dumped the maintenance of the galleries and stopped defending their access. Thus, the relevance of the use of nests can only be evaluated in a study that takes into account the community of terrestrial isopods in and out of nests, considering especially species occurrence and abundance in the environment surroundings.

It may be noted that the termite nests studied here were constructed by a single genus of termite, Nasutitermes. There are 38 known species and 27 genera of termites in primary and secondary forests of Ilhéus (Reis \& Cancello 2007) and it is expected that the same or other species of terrestrial isopods will be found in nests of other taxa of termites.

\section{Acknowledgements}

To CAPES for a scholarship awarded to JTL, CNPq for the Productivity Grant awarded to JHCD and PBA, and the Comissão Executiva do Plano da Lavoura Cacaueira (CEPLAC) for access to the experimental laboratory and lab support. To Dr A. Raw for the critical review of the manuscript.

\section{References}

AGARWAL, V.B. 1979. Temperature and relative humidity inside the mound of Odontotermes obesus (Rambur) (Isoptera: Termitidae). Proc. Indian Acad. Sci. 89(2):91-99.

ALMERÃO, M.P., MENDONÇA JUNIOR, M.S., QUADROS, A.F., PEDÓ, E., SILVA, L.G.R. \& ARAUJO, P.B. 2006. Terrestrial isopod diversity in the subtropical neotropics: Itapuã State Park, southern Brazil. Iheringia Ser. Zool. 96(4):473-477. http://dx.doi.org/10.1590/S007347212006000400012

ARAUJO, P. B. \& BOND-BUCKUP, G. 2005. Population structure and reproductive biology of Atlantoscia floridana (van Name, 1940) (Crustacea, Isopoda, Oniscidea) in southern Brazil Acta Oecol. 28:289298. http://dx.doi.org/10.1016/j.actao.2005.05.005

ARAUJO, P.B. \& TAITI, S. 2007. Terrestrial isopods (Crustacea, Oniscidea) from Rocas Atoll, northeastern Brazil. Arq. Mus. Nac. 65:347-355.

BARNARD, K. 1932. Contribution to the fauna of South Africa. 11. Terrestrial Isopoda. Ann. South Afr. Mus. 30:179-388.

BORUTZKII, E. V. 1969. A new family Turanoniscidae fam. n. (Isopoda, Oniscoidea) from termitaria of Middle Asia. Zool. Zh. 48:499-504.

BRIGHTSMITH, D. J. 2005. Competition, predation and nest niche shifts among tropical cavity nesters: phylogeny and natural history evolution of parrots (Psittaciformes) and trogons (Trogoniformes). J. Avian Biol. 36:64-73. http://dx.doi.org/10.1111/j.0908-8857.2005.03310.x

CAMARGO, J.M.F. 1970. Ninhos e biologia de algumas espécies de Meliponídeos da região de Pôrto Velho, Território de Rondônia, Brasil. Ver. Biol. Trop. 16:207-239.

CAMPOS-FILHO, I.S., LISBOA, J.T. \& ARAUJO, P.B. 2013. Review of Atlantoscia Ferrara \& Taiti, 1981 (Crustacea: Isopoda: Oniscidea: Philosciidae) with new records and new species. Org. Divers. Evol. 1:1-23.

CUNHA, H.F. \& BRANDÃO, D. 2000. Invertebrates associated with the Neotropical termite Constrictotermes cyphergaster (Isoptera: Termitidae, Nasutitermitinae). Sociobiol. 3:593-599.

DAVIS, D.E. 1942. The Phylogeny of Social Nesting Habits in the Crotophaginae. Q. Rev. Biol. 17(2):115-134. http://dx.doi. org/10.1086/394650

DOMINGOS, D.J. 1983. O ninho de Armitermes euamignathus (Isoptera, Termitidae), características gerais, crescimento e associações. Cienc. Cult. 35:783-789.

FERRARA, F. \& TAITI, S. 1979. A check-list of terrestrial isopods from Africa (south of the Sahara). Monit. Zool. Ital. 12:89-215.

FERRARA, F., MASCHWITZ, U., KOVAC, S. \& TAITI, S. 1987. The genus Exalloniscus Stebbing, 1911 (Crustacea, Oniscidea) and its relationship with social insects. - Pubbl. Ist. Ent. Univ. Pavia. 36:43-46.

GRASSÉ, P.-P. 1986. Termitologia: Anatomie - Physiologie - Biologie - Systématique des Termites, Tome III Comportement - Socialité - Écologie - Évolution - Systématique. Masson, Paris, p.715.

HOLT, J.A. \& LAPAGE, M. 2000. In Termites: evolution, sociality, symbiosis, ecology (T. H. M. Abe \& D. E. Bignell, eds.). Kluwer Academic Publishers, Dordrecht, p.389-407.

HORNUNG, E., VILISICS, F. \& TARTALLY, A. 2005. Occurrence of Platyarthrus schoblii (Isopoda, Oniscidea) and its ant hosts in Hungary. Eur. J. Soil Biol. 41:129-133. http://dx.doi.org/10.1016/j. ejsobi.2005.11.001 
KENSLEY, B. 1971. Termitophilous isopods from southern Africa. - Ann. S. Afr. Mus. 57:131-147.

LAVELLE, P., BIGNELL, D. \& LAPAGE, M. 1997. Soil function in a changing World: The role of invertebrate ecosystems engineers. Eur. J. Soil Biol. 33(4):159-193.

LEISTIKOW, A. 2001. Phylogeny and biogeography of South American Crinocheta, traditionally placed in the family "Philosciidae" (Crustacea: Isopoda: Oniscidea). Org. Divers. Evol. 1, Electr. Suppl. 4:1-85.

LEMOS DE CASTRO, A. 1970. Isópodos terrestres do gênero Neotroponiscus arcangeli (Oniscidae: Bathytropinae). An. Acad. Bras. Cienc. 42:89-95.

LEMOS DE CASTRO, A. 1973. Pudeoniscidae, família nova, com descrição de um gênero novo e três espécies novas de isópodos terrestres do Brasil (Isopoda, Oniscoidea). Bol. Mus. Nac. 287:1-10, figs 1-5.

LEMOS DE CASTRO, A. 1985. Considerações sobre Atlantoscia alceui Ferrara \& Taiti, 1981 (Isopoda, Oniscoidea, Philosciidae). Rev. Bras. Biol. 45(4):417-442.

LOPES, E.R.C., MENDONÇA JUNIOR, M.S., BOND-BUCKUP, G. \& ARAUJO, P.B. 2005. Oniscidea diversity across three environments in an altitudinal gradient in northeastern Rio Grande do Sul, Brazil. Europ. J. Soil Biol. 41:99-107 http://dx.doi.org/10.1016/j.ejsobi.2005.11.002

MAGRINI, M.J., ARAUJO, P.B. \& UEHARA-PRADO, M. 2010. Crustacea, Isopoda, Oniscidea Latreille, 1802: New continent record and distribution extension in Brazil. Check List. 6(2):217-219.

MIURA, T. \& MATSUMOTO, T. 1997. Diet and nest material of the processional termite Hospitalitermes and cohabitation of termes (Isoptera, Termitidae) on Borneo Island. Insectes Soc. 44:267-275. http://dx.doi. org/10.1007/s000400050047

PAULIAN DE FÉLICE, L. 1950. Oniscoïdes nouveaux de Madagascar. Nat. Malgache. 2:101-106.

PODGAISKI, R.L., OTT, R. \& GANADE, G. 2007. Ocupação de microhábitats artificiais por invertebrados de solo em um fragmento florestal no sul do Brasil. Neotrop. Biol. Conserv. 2(2):71-79.

QUADROS, A.F. \& ARAUJO, P.B. 2008. An assemblage of terrestrial isopods in southern Brazil and its contribution to leaf litter processing. Rev. Bras. Biol. 25(1):58-66.

REIS, Y.T. \& CANCELLO, E.M. 2007. Riqueza de cupins (Insecta, Isoptera) em áreas de mata atlântica primária e secundária do Sudeste da Bahia. Iheringia. 97(3):229-234. http://dx.doi.org/10.1590/S007347212007000300001
SANCHEZ-MARTINEZ, T.C. \& RENTON, K. 2009. Availability and selection of arboreal termitaria as nest-sites by Orange-fronted Parakeets Aratinga canicularis in conserved and modified landscapes in Mexico. Ibis. 151(2):311-320. http://dx.doi.org/10.1111/j.1474919X.2009.00911.x

SANTOS, P.P. 2008. Fauna associada a ninhos de térmitas em um cacaual no municipio de Ilhéus, Bahia. Dissertação de mestrado, Universidade Estadual de Santa Cruz, Ilhéus.

SANTOS, P.P.; VASCONCELLOS, A.; JAHYNY, B. \& DELABIE, J.H.C. 2010. Ant fauna (Hymenoptera; Formicidae) associated to arboreal nests of Nasutitermes spp. (Isoptera, Termitidae) in a cacao plantation in southerrn Bahia, Brazil. Rev. Bras. Entomol. 54(3):450-454. http:// dx.doi.org/10.1590/S0085-56262010000300016

SCHMALFUSS, H. 1984. Eco-morphological strategies in terrestrial isopods. Sym. Zool. S. 53:49-63.

SCHMALFUSS, H. 2003. World catalog of terrestrial isopods (Isopoda, Oniscidea). Stuttgarter Beitr. Naturk. 654:1-341.

SCHMIDT, C, \& LEISTIKOW, A. 2004. Catalogue of genera of the terrestrial Isopoda (Crustacea: Isopoda: Oniscidea). Steenstrupia. 28(1):1-118.

SILVESTRI, F. 1917. Contribuzione alla conoscenza dei termitidi e termitofili dell'Africa occidentale. II. Termitofili. Parte prima. Arthropoda. Crustacea. Isopoda. - Boll. Lab. Zool. Gen. Agr. R. Scuola Sup. Agricol. Portici. 12:290-294.

SOUZA-KURY, L. 1998. Malacostraca. Peracarida. Isopoda. Oniscidea. In: Catalogue of Crustacea of Brazil (P. Young, ed.). Rio de Janeiro, p.653-674.

TAITI, S. \& FERRARA, F. 1988. Revision of the genus Exalloniscus Stebbing, 1911 (Crustacea: Isopoda: Oniscidea). Zool. J. Linn. Soc. 94:339-377. http://dx.doi.org/10.1111/j.1096-3642.1988.tb01200.x

TARTALLY, A., HORNUNG, E. \& ESPADALER, X. 2004. The joint introduction of Platyarthrus schoblii (Isopoda: Oniscidea) and Lasius neglectus (Hymenoptera: Formicidae) into Hungary. - Myrmec. Nach. 6:61-66.

XIAO, B., CHEN, A.-H. ZHANG, Y.-Y. JIANG, G.-F. HU, C.-C. \& ZHU, C.-D. 2012. Complete mitochondrial genomes of two cockroaches, Blattella germanica and Periplaneta americana, and the phylogenetic position of termites. Curr. Genet. 58:65-77. PMid:22311390. http://dx.doi. org/10.1007/s00294-012-0365-7 